\title{
A realization of pauses in utterance across speech style, gender, and generation*
}

\author{
Doyoung Yoo $\cdot$ Jiyoung Shin $^{* *}$ \\ Department of Korean Language and Literature, Korea University, Seoul, Korea
}

\begin{abstract}
This paper dealt with how realization of pauses in utterance is affected by speech style, gender, and generation. For this purpose, we analyzed the frequency and duration of pauses. Pauses were categorized into four types: pause with breath, pause with no breath, utterance medial pause, and utterance final pause. Forty-eight subjects living in Seoul were chosen from the Korean Standard Speech Database. All subjects engaged in reading and spontaneous speech, through which we could also compare the realization between the two speech styles. The results showed that utterance final pauses had longer durations than utterance medial pauses. It means that utterance final pause has a function that signals the end of an utterance to the audience. For difference between tasks, spontaneous speech had longer and more frequent pauses because of cognitive reasons. With regard to gender variables, women produced shorter and less frequent pauses. For male speakers, the duration of pauses with breath was significantly longer. Finally, for generation variable, older speakers produced more frequent pauses. In addition, the results showed several interaction effects. Male speakers produced longer pauses, but this gender effect was more prominent at the utterance final position.
\end{abstract}

Keywords: pause, socioloinguistics, sociophonetics, speech style, speech task, gender, generation

\section{1. 서론}

대부분의 말소리는 부아 날숨의 발동 과정을 통해서 산출된 다. 하지만 폐에서 내보낼 수 있는 기류의 양은 제한적이기 때문 에 발화를 지속하기 위해서는 들숨을 통해 지속적으로 기류를 보충할 필요가 있다. 들숨을 쉬는 동안에는 음성을 산출하지 못
하기 때문에 발화를 이어가는 과정에서 휴지의 출현은 불가피 하다. 그런데 발화 내에서 관찰되는 휴지는 호흡만을 위한 것이 아니다. 발화의 기획을 위한 시간을 벌기 위해서, 뒤에 올 말을 강조하거나 청자의 주목을 그는 등 발화 전략상의 목적을 위해 서, 또 자신의 발화 실수를 자각하거나 발화 수정의 필요성을 느껴 수정을 하는 과정에서도 휴지는 관찰된다. 또한, Shin(2018)

\footnotetext{
* This work was supported by the Ministry of Education of the Republic of Korea and the National Research Foundation of Korea (NRF-2017S1A5A2A01024742). This work was supported by NRF (National Research Foundation of Korea) Grant funded by the Korean Government (NRF-2018-Global Ph.D. Fellowship Program)

**shinjy@korea.ac.kr, Corresponding author Received 3 May 2019; Revised 12 June 2019; Accepted 17 Jnue 2019

(c) Copyright 2019 Korean Society of Speech Sciences. This is an Open-Access article distributed under the terms of the Creative Commons Attribution NonCommercial License (http://creativecommons.org/licenses/by-nc/4.0) which permits unrestricted non-commercial use, distribution, and reproduction in any medium, provided the original work is properly cited.
} 
에서 논의했듯이 휴지의 기능은 화자를 위한 것이기도 하지만 청자를 위한 것이기도 하다. 청자의 입장에서 발화는 실시간 처 리해야 하는 긴 길이의 정보 연쇄이기 때문에 발화는 인간이 지 니는 기억의 한계를 고려하여 정보가 담긴 부분과 정보를 처리 할 수 있는 시간을 주는 부분으로 구성되어야 한다. 따라서 휴지 의 기능 중 하나는 청자에게 발화 정보가 처리될 수 있는 시간 을 주기 위한 것으로 이해할 수 있다.

이처럼 휴지는 발화에서 다양한 기능을 가지고 실현된다. 기 류 조달을 위한 생리적인 이유뿐 아니라, 통사적 단위나 운율적 단위의 경계 표시와 같은 언어적 이유 혹은 발화 계획과 정보 처리를 위한 인지적인 이유까지 휴지는 인간의 언어 행위에서 여러 기능을 갖는다. 이런 휴지 실현에 영향을 주는 요인들은 언어적이고 인지적인 요인뿐 아니라, 연령이나 성별에 따라 달 라지는 생리적인 요인까지 매우 다양할 것으로 예측된다.

실제로 휴지는 문법적이거나 인지적인 이유로 인해서 그 실 현 양상이 달라질 수 있다. 이미 여러 연구들에서 인지적인 부담 량이나 통사적인 복잡성이 휴지 길이와 빈도에 영향을 준다는 결과가 보고되어 왔다(Cappella, 1985; Ferreira, 1991; Grosjean et al., 1979; Henderson et al., 1966; Smith, 2004). 이러한 연구들에서 공통적으로 설명한 것은 화자가 단어 선택에 대한 더 많은 감시 (monitor)나 계획이 요구되는 상황에서 더 큰 인지적 부담을 느 끼고, 이러한 상황이 더 많은 휴지의 사용을 야기한다는 것이다. 이는 발화를 계획하는 상황에서 더 긴 길이의 휴지가 나타남을 암시한다.

낭독발화와 자유발화 간 비교를 통해서 발화 계획 여부와 휴 지의 실현 간의 상관관계를 확인할 수 있다. 자유 발화와 낭독 발화에서 관찰되는 휴지의 빈도를 살핀 Henderson et al.(1965)에 서는 호흡 동반 휴지와 호흡을 동반하지 않은 휴지의 빈도가 모 두 자유발화에서 높게 나타나는데, 특히 호흡이 동반되지 않은 휴지의 빈도가 더 큰 차이를 보인다고 보고하였다. 또 자유 발화 에서 긴 휴지와 짧은 발화 길이가 관찰된 점을 언급하며, 이러 한 패턴이 발화 계획과 관련되어 있다고 설명했다. 다시 말해 화 자의 발화 계획이 필요한 자유 발화에서는 후행 발화를 생각하 기 위해 더 긴 휴지가 나타나며, 휴지와 휴지 사이의 발화의 양 은 더 짧다는 것이다. 또, Goldman-Eisler(1972)에서도 자유 발화 와 낭독 발화의 휴지 실현 양상을 분석하였다. 분석 결과를 바 탕으로 유창성을 측정하였는데, 그 결과 자유 발화보다 낭독 발 화의 유창성 점수가 높게 나타나는 것을 확인할 수 있었다. 이 렇게 과제 간 휴지 실현 양상의 차이가 존재한다는 사실을 통해, 발화 문장을 구성하기 위한 인지적 부담이 클수록 길고 빈번한 휴지가 관찰되는 것이 일반적인 사실임을 확인할 수 있다.

과제에 따른 차이 이외에도 성별, 연령과 같은 사회언어학적 변수들이 휴지의 실현과 밀접하게 관련이 있다는 것이 여러 연 구들에서 보고되었다. 휴지의 실현은 기본적으로 호흡과 관련 이 있으며, 또 발화 속도와도 밀접한 관련이 있기 때문에 이는 생리적 차이에 의한 실현 양상의 변이를 필연적으로 반영할 것 이다. 또한 사회적 변수들은 발화자의 사회·문화적 지위에 따른 특성을 담고 있으므로 어떤 언어 현상은 그 언어의 사회적 현실
을 반영하고 있다고 할 수 있다. 따라서 사회언어학적 변수에 따 른 실현을 살펴보는 것은 의미가 있다.

실제로 영어를 대상으로 성별에 따른 휴지 실현을 살핀 Whiteside(1995)와 Kendell(2009)은 성별에 따라 휴지의 실현에 차이가 있음을 보였는데, Whiteside(1995)는 남성의 발화보다 여성의 발화에서 더 긴 휴지 길이가 관찰된다고 보고한 반면, Kendell(2009)은 남성이 대체로 여성보다 긴 휴지 길이를 보인다 고 하여 상반된 결과를 제시하였다. 또 성별과 연령에 따른 휴 지 실현을 연구한 Kowal et al.(1975), Kowal \& O'Connell(1980)에 서는 남녀 간 차이가 어린 화자들 사이에서만 일관된다고 밝혔 는데, 어린 남성이 어린 여성보다 더 길고 많은 휴지를 산출한 다고 하였다.

그런데 사회언어학적 변수에 따른 휴지 실현을 살핀 연구의 대부분은 영어나 유럽어 중심으로 이루어져 있으며, 한국어에 대한 연구는 찾기 어렵다. 다만 한국어 발화 속도의 세대, 성별, 지역적 차이를 고찰한 Lee et al.(2017)에서 휴지에 대해 언급한 바가 있다. 해당 연구에서는 세대 간 성별 간 발화 속도의 유의 미한 차이가 있음을 밝히는 과정에서 발화 속도의 차이가 휴지 부의 비율과 빈도의 차이에서 기인한다고 설명하였다. 그러나 구체적으로 어떤 종류의 휴지가 어떤 위치에서 어떠한 양상을 보이며 출현하는지는 살피지 않았다.

성별, 연령과 같은 변수들은 생리적이고 신체적인 차이를 반 영하기도 하지만, 사회·문화적인 차이에 의한 특성을 반영하는 변수이기도 하다. 사회언어학적 변수에 따른 언어의 실현은 범 언어적인 공통점을 갖기도 개별언어에 따른 차이를 보이기도 하므로 언어 개별적인 연구의 필요성이 요구된다. 따라서 이러 한 사회언어학적 변수들이 한국어 발화에 어떠한 영향을 미치 는지 탐구해야할 필요가 있다.

선행연구의 검토를 통해 사회언어학적 변수나 인지적인 요 인으로 인해 휴지의 실현이 달라질 수 있음을 확인할 수 있었다. 하지만 실제 자료의 분석 결과를 바탕으로 연구 결과를 도출한 것은 극히 일부의 경우를 제외하고 대부분이 영어나 유럽어를 연구의 대상으로 삼아 이루어졌다. 한국어의 실제 발화 자료를 대상으로 휴지의 실현 양상을 살펴본 연구는 극히 드물며, 앞서 살펴본 바와 같이 다각적으로 살펴본 연구는 전무하다고 해도 과언이 아니다. 한국어의 경우 구체적으로 어떤 위치에 어떤 종 류의 휴지가 관찰되는지에 대한 정보가 부족하다. 따라서 한국 어를 대상으로 휴지의 실현 양상을 다각도로 살피는 연구가 절 실히 필요한 상황이다.

이에 본 연구에서는 과제, 세대, 성별에 따른 휴지의 실현을 관찰하여 그 양상을 다차원적으로 살피고자 한다. 인지적 차이 를 살피기 위해 낭독 발화와 자유 발화 과제 간 차이를 살펴보 았으며, 또 사회적 차이를 살피기 위해 청년층(20 35세)과 장년 층(50 65세) 간의 세대 차이와 함께 성별에 따른 차이를 관찰하 기 위해 남성 화자 집단과 여성 화자 집단의 발화 자료를 분석 대상으로 삼았다. 


\section{2. 연구 방법}

\section{1. 분석 자료}

본 연구에 사용된 자료는 대규모 구어 코퍼스인 한국인 표준 음성 데이터베이스(Shin \& Kim, 2017) 중 일부다. 이 코퍼스는 전국 9 개 권역, 20 세 이상 남녀 성인을 5 개 연령층으로 나누어 총 3,000 명 이상의 발화를, 발화자의 사회적 요소가 균형을 가질 수 있도록 고려하여 수집하고 구축된 대규모 음성 코퍼스이다. 본 연구에서는 이 가운데 수도권 청·장년층 남녀 화자 총 48 명 의 발화 자료를 연구의 대상으로 삼았다. 청년층은 20 세에서 35 세 사이, 장년층은 50 세에서 65 세 사이의 나이를 갖는 집단으 로 조작적 정의를 내리고, 전체 코퍼스 가운데 위 조건에 맞는 피험자를 임의로 선정하여 분석 대상으로 삼았다. 이에 따라 선 정된 피험자의 나이는 청년층 평균 27.8( \pm 4.1$)$ 세, 장년층 평균 $56.7( \pm 4.7)$ 세였다.

그리고 피험자들이 수행한 다섯 가지 발화 과제(모음 발성, 문단 낭독, 문장 낭독, 괄호 메워 말하기, 자유 발화) 중에서 문 단 낭독과 자유 발화 자료를 연구의 대상으로 삼았다. 낭독 발 화 자료는 모든 발화자의 자료가 연구 대상이 되었지만, 자유발 화 자료의 경우에는 선정된 48명의 피험자 중 비 유창한 발화 및 부적절한 과제 수행이 관찰된 3 명의 발화 자료가 분석에서 제외 되었다. 분석 대상이 된 피험자를 과제별로 세대와 성별을 구분 하여 제시하면 표 1 에 보인 것과 같다.

표 1. 낭독/자유 발화 피험자 수(단위, 명)

Table 1. The number of subjects for read/spontaneous speech

\begin{tabular}{c|c|c|c}
\hline & 남(낭독/자유) & 여(낭독/자유) & 계 \\
\hline 청년층 & $12 / 12$ & $12 / 12$ & $24 / 24$ \\
\hline 장년층 & $12 / 10$ & $12 / 11$ & $24 / 21$ \\
\hline 계 & $24 / 22$ & $24 / 23$ & $48 / 45$ \\
\hline
\end{tabular}

분석 대상이 된 문단 낭독 자료는 전 연령층이 공통으로 낭독
한 한 개 문단이었다. 해당 문단은 총 11 개 문장, 59 개 어절, 176 음절로 구성되어 있다1. 한편, 자유 발화는 피험자가 자발적으 로 발화한 약 3 분가량의 독백 발화 자료였다. 분석 대상이 된 자 료의 규모는 문단 낭독의 경우 48 명이 발화한 2,441 어절이었고, 자유 발화의 경우 45 명이 발화한 13,354 어절이었다. 따라서 분 석 대상 자료의 분량은 총 13,795 어절이었다.

\section{2. 분석 방법}

본 연구에서 휴지는 폐쇄음이나 파찰음의 조음을 위해 실현 된 물리적인 묵음을 제외한, 0.1 초 이상의 물리적인 묵음으로 정 의한다(Clopper \& Smiljanic, 2015; Lee et al., 2017; Shin, 2013; Wennerstrom \& Siegel 2003). 이 정의에 따라 분석 대상 음성 자료 를 어절 단위로 주석하였다. 또 Lee et al.(2017)과 Shin(2018)을 따 라 휴지의 유형을 들숨 동반 여부(들숨 동반, 들숨 비동반)와 휴 지의 운율적 위치(발화 말, 발화 내)에 따라서 네 가지 유형으로 나누어 주석하였다. 휴지의 네 가지 유형은 각각 들숨 동반 발 화 말 휴지 $(<\mathrm{SIL}>\mathrm{B})$, 들숨 동반 발화 내 휴지 $(<\mathrm{SP}>\mathrm{B})$, 들숨 비동 반 발화 말 휴지 $(<\mathrm{SIL}>)$, 들숨 비동반 발화 내 휴지 $(<\mathrm{SP}>)$ 였다.

휴지 기간 동안의 들숨 동반 여부는 스펙트로그램을 참고하 여 연구자가 듣고 판단하였다. 본 연구의 연구 대상이 된 녹음 자료가 대부분 녹음실 혹은 소음이 적은 환경에서 수집되었기 때문에 들숨이 동반된 휴지의 경우 거의 대부분 들숨으로 인한 마찰 소음이 스펙트로그램 상에서 관찰되었다.

한편, 발화 단위 주석은 종결 어미의 실현 및 발화 말에 실현 된 특징적인 운율(종결 억양)과 함께 의미를 고려하여 연구자가 판단하였다. 낭독 발화의 경우는 대본이 문장 단위로 구성되어 있었기 때문에 피험자들이 문장 단위를 발화 단위로 실현하였 다. 따라서 문단 낭독의 경우, 제시된 대본의 한 문장 단위가 발 화 단위와 일치했고, 그 결과 문단 낭독은 총 11 개의 발화가 관 찰되었다. 하지만 자유 발화의 경우는 문단 낭독처럼 문장의 종 결이 종결 어미에 의해 실현되지 않은 경우가 많았다. 하지만

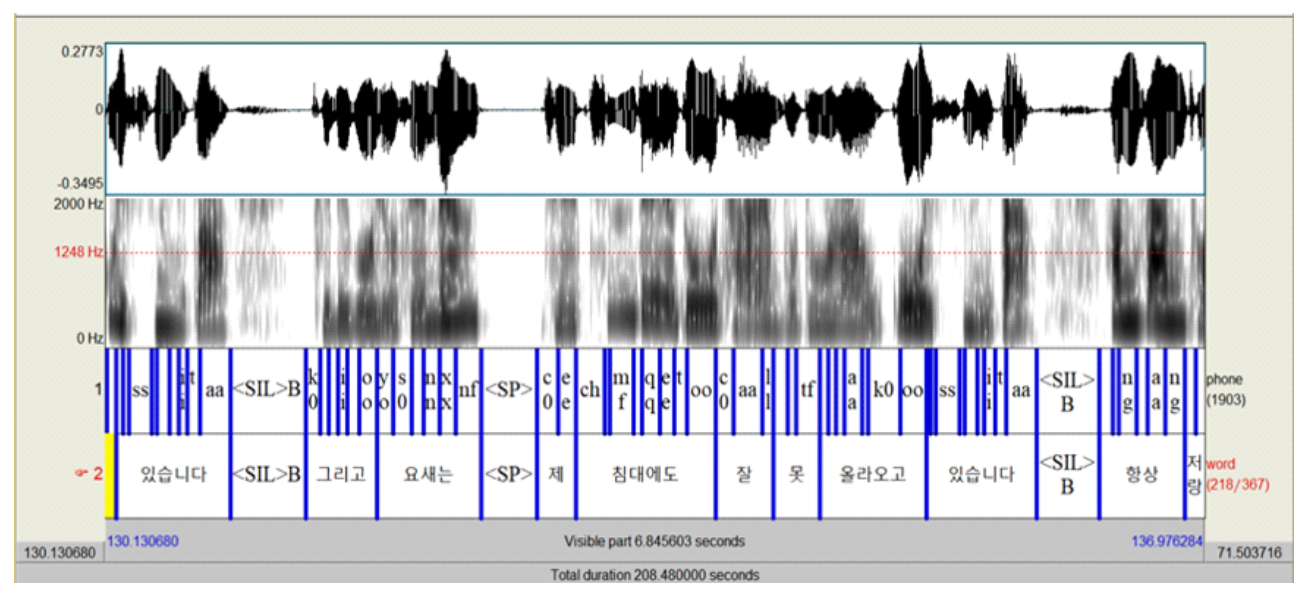

그림 1. Praat을 이용한 휴지 주석 예시. $<\mathrm{SIL}>$ : 발화 말 휴지부, $<\mathrm{SP}>$ : 발화 내 휴지부, B: 들숨 동반

Figure 1. Example annotations using Praat, $<\mathrm{SIL}>$ : utterance final pause, $<\mathrm{SP}>$ : utterance medial pause, $\mathrm{B}$ : with breath

1 대본은 [부록 1]에 제시하였다. 
공적 말하기 성격이 강해서 본 연구에서 설정한 종결 어미의 실 현 및 종결 억양의 실현 그리고 의미적 특징을 고려하여 판단하 는 데 크게 어려움은 없었다.

또, 발화 중간에 웃음이 섞인 부분이나 지나치게 비유창한 부 분은 분석 대상에서 제외하였다. 또한, 2 초 이상의 긴 휴지가 실 현된 경우도 비유창한 발화의 일부로 보고 분석 대상에서 제외 하였다. 그림 1 은 이와 같은 분석 기준에 따라 분석 대상 자료를 주석한 예를 보인 것이다.

본 연구에서 설정한 분석 방법을 바탕으로 휴지의 유형별 출 현 빈도 및 길이를 측정하였다. 휴지 빈도는 분당 휴지의 출현 회수로, 휴지 길이는 ms 단위로 측정하였다.

통계 분석에는 R 프로그램이 사용되었다. 한 화자에 대해 여 러 개의 데이터 포인트가 있는 휴지 길이는 화자를 임의 효과로 하는 혼합 효과 모형(mixed effect model)을 통해 분석하였고, 한 화자에 하나의 데이터 포인트가 있는 휴지 빈도는 선형 회귀 모 형(linear regression model)을 통해 분석하였다.

\section{3. 결과}

이 장에서는 화제, 성별, 세대에 따른 휴지의 빈도, 휴지의 길 이의 실현 양상을 보일 것이다. 먼저 과제, 성별, 세대에 따른 휴 지의 빈도 실현을 먼저 관찰하고 휴지 길이에 대해 살펴볼 것이 다. 휴지의 길이는 전체적인 휴지 길이를 먼저 살핀 후, 이를 다 시 들숨 동반 여부에 따라 들숨 동반 휴지와 들숨 비동반 휴지 로 나누어 볼 것이다.

\section{1. 휴지의 빈도}

휴지의 빈도는 분당 휴지 출현 빈도로 살펴보았다. 휴지 빈도 가 각 범주별로 유의한 차이를 보이는지 살피기 위하여 과제, 성 별, 세대를 독립 변수로 하여 휴지 빈도를 예측하는 선형 회귀 분석을 수행하였다. 통계 검정 결과 과제, 성별, 세대 모두에서 통계적으로 유의한 차이를 관찰할 수 있었다. 표 2는 범주별 평 균 분당 휴지 출현 빈도와 통계 검정 결과를 제시한 것이다.

표 2. 과제, 성별, 세대에 따른 평균 분당 휴지 출현 빈도와 선형 회귀 분석 결과( $\beta$, 예측값; $t, t$ 값)

Table 2. Mean pause frequency per minute for each speech style, gender and generation and statistical results from linear regression model ( $\beta$,estimated value; $t, t$ score)

\begin{tabular}{c|c|c|c|c}
\hline \multirow{2}{*}{ 분류 } & 소분류 & $\begin{array}{c}\text { 분당 평균 휴지 출현 빈도 } \\
( \pm \text { 표준 편차) }\end{array}$ & $\beta$ & $t$ \\
\hline \multirow{2}{*}{ 과제 ${ }^{* * *}$} & 낭독 발화 & $21.9( \pm 5.62)$ & -2.08 & -4.1 \\
\cline { 2 - 5 } & 자유발화 & $26.0( \pm 4.77)$ & & \\
\hline \multirow{2}{*}{ 성별** } & 남성 & $25.3( \pm 5.99)$ & 1.4 & 2.75 \\
\cline { 2 - 5 } & 여성 & $22.5( \pm 4.86)$ & & \\
\hline \multirow{2}{*}{ 세대 ${ }^{*}$} & 청년 & $22.9( \pm 4.64)$ & -1.07 & -2.1 \\
\cline { 2 - 6 } & 장년 & $24.9( \pm 6.34)$ & & \\
\hline${ }^{*} p<0.05,{ }^{* *} p<0.01,{ }^{* * *} p<0.001$. &
\end{tabular}

표에 보인 바와 같이, 자유 발화의 평균 분당 휴지 출현 빈도
는 26회로 낭독 발화의 평균 21.9회보다 높았다 $[F(1,85)=16.28$, $p<.001]$. 또 남성은 평균 25.3회로 22.5 회인 여성보다 더 빈번한 휴지 출현을 보였다 $[F(1,85)=7.54, p<.01]$. 마지막으로 세대의 경 우는 평균 22.9회로 나타난 청년층보다 24.9회의 출현을 보인 장 년층이 발화에서 더 빈번하게 휴지를 실현한 것으로 나타났다 $[F(1,85)=4.61, p<.05]$.

이밖에 휴지의 빈도에 영향을 줄 수 있는 변수 간 상호작용은 관찰되지 않았다. 이는 곧 과제, 성별, 세대 모두에서 범주별로 일관된 경향을 보였다는 것을 의미한다. 즉, 낭독 발화보다는 자 유 발화가, 여성보다는 남성이, 청년층보다는 장년층이 발화 시 더 빈번한 휴지를 보인다는 것을 관찰할 수 있다.

\section{2. 휴지의 길이}

\subsection{1. 전체적인 실현 양상}

이 절에서는 들숨 동반 휴지와 들숨 비동반 휴지를 아우른 전 반적인 휴지 길이의 실현 양상을 살폈다. 이를 통해 휴지 길이가 전체적으로 발화에서 어떠한 양상을 보이는지 관찰해 보았다.

휴지 길이에 영향을 미치는 요인을 확인하기 위하여 혼합 효 과 회귀 분석을 수행하였다. 휴지의 실현 위치, 과제, 성별, 세대 를 독립 변수, 개별 화자를 임의 변수로 설정하여 휴지 길이에 대한 모델을 생성하였다. 표 3 은 변수에 따른 평균 휴지 길이와 혼합 효과 회귀 분석에 따른 결과를 제시한 것이다.

표 3. 실현 위치, 과제, 성별, 세대에 따른 평균 휴지 길이(단위: $\mathrm{ms}$ )와 다중 회귀 분석 결과( $\beta$, 예측값; $t, t$ 값)

Table 3. Mean duration (ms) of whole pauses for each place of pauses, speech style, gender and generation and statistical results from mixed effect regression model ( $\beta$, estimated value; $t, t$ score)

\begin{tabular}{|c|c|c|c|c|}
\hline 분류 & 소분류 & $\begin{array}{c}\text { 평균 휴지 길이 } \\
\text { ( } \pm \text { 표준 편차) }\end{array}$ & $\beta$ & $t$ \\
\hline \multirow{2}{*}{ 실현 위치 ${ }^{* * *}$} & 발화 내 & $526( \pm 356)$ & -149.69 & -12.19 \\
\hline & 발화 말 & $698( \pm 389)$ & & \\
\hline \multirow{2}{*}{ 과제 ${ }^{* * *}$} & 낭독 발화 & $523( \pm 273)$ & -120.62 & -6.53 \\
\hline & 자유 발화 & $577( \pm 387)$ & & \\
\hline \multirow{2}{*}{ 성별 ${ }^{* * *}$} & 남성 & $604( \pm 399)$ & 64.82 & 3.507 \\
\hline & 여성 & $531( \pm 337)$ & & \\
\hline \multirow{2}{*}{ 세대 } & 청년 & $551( \pm 347)$ & -13.69 & 0.74 \\
\hline & 장년 & $587( \pm 396)$ & & \\
\hline
\end{tabular}

**** $p<0.001$.

표에서 확인할 수 있듯이 평균 휴지 길이는 실현 위치에 따라 발화 내(526 ms)가 발화 말 $(698 \mathrm{~ms})$ 보다 $(p<0.001)$, 낭독 발화(523 $\mathrm{ms})$ 가 자유 발화 $(577 \mathrm{~ms})$ 보다 유의미하게 짧은 것으로 나타났다 $(p<0.001)$. 또, 여성의 평균 휴지 길이는 $531 \mathrm{~ms}$ 로 관찰되어, 남성 에서 관찰된 평균 휴지 길이인 $604 \mathrm{~ms}$ 보다 유의미하게 짧았다 $(p<0.001)$. 한편, 세대 간 차이를 살펴보면, 청년층이 $551 \mathrm{~ms}$, 장 년층은 $587 \mathrm{~ms}$ 를 보여서, 청년층이 장년층보다 다소 짧은 것으 로 나타났지만, 이 차이는 통계적으로 유의미한 차이는 아니었 다 $(p>0.05)$.

단일 변수에 따른 주효과 이외에도 휴지 길이에 영향을 주는 변수 간 상호 작용역시 관찰되었다. 표 4는 휴지 길이에 유의하 
게 영향을 주는 변수 간 상호 작용 효과의 통계 검정 결과를 제 시한 것이다. 표 4에서 알 수 있듯이 실현 위치와 성별 간 상호 작용이 휴지 길이 실현에 영향을 주었다.

표 4. 휴지 길이에 영향을 주는 변수 간 상호 작용 효과 ( $\beta$, 예측값; $t, t$ 값)

Table 4. Interaction effect about duration of pauses ( $\beta$, estimated value; $t, t$ score)

\begin{tabular}{c|c|c}
\hline & $\beta$ & $t$ \\
\hline 실현 위치(발화 내): 성별(남성) ${ }^{*}$ & -26.15 & -2.1 \\
\hline${ }^{*} p<0.05$.
\end{tabular}

이 두 변수에 따라 휴지의 길이가 어떤 실현 양상을 보이는지 확인하기 위해 그린 그래프가 그림 2와 같다. 이 그림은 실현 위 치에 따른 성별 휴지 길이의 평균값을 제시한 것이다. 실선은 남 성, 점선은 여성이고 그림의 왼쪽은 발화 내 휴지 길이, 오른쪽 은 발화 말 휴지 길이이다.

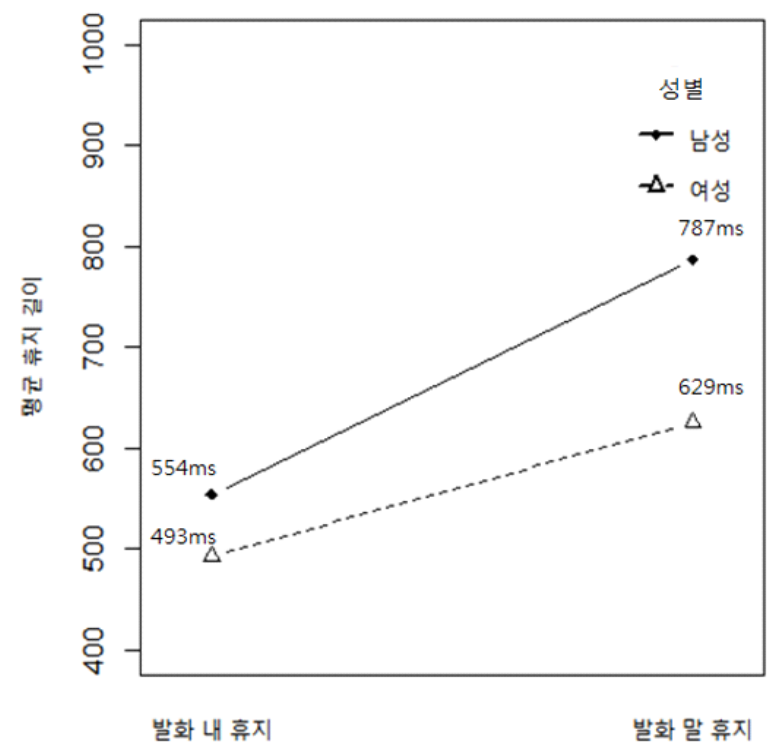

그림 2. 실현 위치와 성별 간 상호 작용(x축, 실현 위치; $\mathrm{y}$ 축, 평균 휴지 길이 $(\mathrm{ms})$; 실선, 남성; 점선, 여성)

Figure 2. Interaction between the place of pauses and generation ( $\mathrm{x}$ axis, place of pauses; $y$ axis, mean duration of pauses (ms); full line, male speakers; dotted line, female speakers)

이 그림을 통해 남성이 여성보다 전체적으로 긴 휴지를 두고 발화하는데, 특히 그 차이가 발화 말 위치에서 두드러진다는 것 을 확인할 수 있다. 발화 내 휴지 길이의 남녀 평균값 차이는 61 $\mathrm{ms}$ 에 불과한 반면, 발화 말 휴지 길이의 남녀 차이는 약 $161 \mathrm{~ms}$ 이었다.

요약하면, 전체 휴지 길이는 실현 위치, 과제, 성별에서 유의 미한 차이가 관찰되었으나, 세대에서는 유의미한 차이를 관찰 할 수 없었다. 발화 내보다는 발화 말에서, 낭독 발화보다 자유 발화에서 유의미하게 더 긴 휴지가 관찰되었다. 한편, 남성이 여 성보다 더 긴 휴지를 실현시키며 발화를 이어가는 것을 확인할
수 있었는데, 이러한 성별 차이는 발화 내 휴지보다 발화 말 휴 지에서 더 두드러졌다.

\subsection{2. 들숨 동반 여부에 따른 실현 양상}

이 절에서는 3.2.1.에서 살펴본 휴지를 들숨 동반 여부에 따라 구분하여 살펴본다. 들숨 동반 휴지 길이는 화자가 호흡을 위해 숨을 들이쉴 때 얼마만큼의 쉼을 지속하는지 알아보기 위해 측 정한 것이다. 이것이 들숨 비동반 휴지와 어떠한 차이를 보이는 지 관찰할 것이다.

\subsubsection{1. 들숨 동반 휴지}

들숨 동반 휴지 길이에 영향을 미치는 요인을 알아보기 위하 여 실현 위치, 과제, 성별, 세대를 종속변수로, 화자를 임의 변수 로 한 혼합 효과 회귀 분석을 수행했다. 표 5 는 범주별 평균 들숨 동반 휴지 길이와 통계 검정에 따른 결과를 정리한 것이다.

표 5. 실현 위치, 과제, 성별, 세대에 따른 평균 들숨 동반 휴지 길이(단위: $\mathrm{ms}$ )와 다중 회귀 분석 결과( $\beta$, 예측값; $t, t$ 값)

Table 5. Mean duration (ms) of pauses with breath for each place of pauses, speech style, gender and generation and statistical results from mixed effect regression model ( $\beta$, estimated value; $t, t$ score)

\begin{tabular}{|c|c|c|c|c|}
\hline 분류 & 소분류 & $\begin{array}{l}\text { 평균 들숨 동반 휴 } \\
\text { 길이 ( } \pm \text { 표준 편차) }\end{array}$ & $\beta$ & $t$ \\
\hline \multirow{2}{*}{$\begin{array}{l}\text { 실현 } \\
\text { 위치 }\end{array}$} & 발화 내 & $573( \pm 306)$ & -121.46 & -6.76 \\
\hline & 발화 말 & $685( \pm 362)$ & & \\
\hline \multirow{2}{*}{ 과제 ${ }^{* * *}$} & 낭독 발화 & $565( \pm 228)$ & -130.3 & -5.21 \\
\hline & 자유 발화 & $623( \pm 351)$ & & \\
\hline \multirow{2}{*}{ 성별** } & 남성 & $689( \pm 355)$ & 70.95 & -2.84 \\
\hline & 여성 & $558( \pm 301)$ & & \\
\hline \multirow{2}{*}{ 세대 } & 청년 & $611( \pm 324)$ & -5.75 & -0.23 \\
\hline & 장년 & $612( \pm 339)$ & & \\
\hline
\end{tabular}

표에 제시된 바와 같이 들숨 동반 휴지 길이의 실현은 휴지의 전반적인 실현 양상과 유사하게 나타났다. 들숨 동반 휴지 길이 의 평균값은 발화 내 $(573 \mathrm{~ms})$ 보다 말화 말 $(685 \mathrm{~ms})$ 이 더 큰 것으 로 나타났다 $(p<0.001)$. 낭독 발화의 평균 들숨 동반 휴지 길이는 $565 \mathrm{~ms}$ 로 자유발화의 $623 \mathrm{~ms}$ 보다 짧았으며 $(p<0.001)$, 남성과 여 성의 평균 들숨 동반 휴지 길이는 각각 $689 \mathrm{~ms}, 558 \mathrm{~ms}$ 로 여성이 남성보다 짧은 휴지를 실현시켰다 $(p<0.01)$. 한편 청년층과 장년 층의 평균 들숨 동반 휴지 길이는 각각 $611 \mathrm{~ms}, 612 \mathrm{~ms}$ 로 차이가 거의 없었고 통계적으로도 유의하지 않았다.

단일 범주에 따른 주효과 이외에 들숨 동반 휴지에 영향을 주 는 변수 간 상호 작용 효과는 관찰되지 않았다. 정리하면, 들숨 동반 휴지에 영향을 주는 요인은 휴지의 실현 위치, 과제, 성별 이었고, 세대는 들숨 동반 휴지에 영향을 주는 요인으로 관찰되 지 않았다. 또한 들숨 동반 휴지에 영향을 주는 변수 간 상호작 용 효과도 관찰되지 않았다. 
3.2.2.2. 들숨 비동반 휴지

들숨을 동반하지 않은 휴지가 실현 위치, 과제, 성별, 세대에 따라 어떠한 실현 양상을 보이는지 살피기 위하여 혼합효과 회 귀 분석을 수행하였다. 앞선 회귀 모델과 동일하게 실현 위치, 과제, 성별, 세대가 종속 변수, 화자가 임의 변수가 되었다. 표 6 은 실현 위치, 과제, 세대, 성별에 따른 들숨 비동반 휴지 길이의 평균값과 통계 검정 결과를 제시한 것이다.

표 6. 실현 위치, 과제, 성별, 세대에 따른 평균 들숨 비동반 휴지 길이(단위: $\mathrm{ms}$ )와 다중 회귀 분석 결과( $\beta$, 예측값; $t, t$ 값)

Table 6. Mean duration (ms) of pauses with no breath for each place of pauses, speech style, gender and generation and statistical results from mixed effect regression model ( $\beta$, estimated value; $t, t$ score)

\begin{tabular}{c|c|c|c|c}
\hline \multirow{2}{*}{ 분류 } & 소분류 & $\begin{array}{c}\text { 평균 들숨 비동반 휴지 } \\
\text { 길이 }( \pm \text { 표준 편차 })\end{array}$ & $\beta$ & $t$ \\
\hline \multirow{2}{*}{$\begin{array}{c}\text { 실현 } \\
\text { 위치*** }\end{array}$} & 발화 내 & $481( \pm 386)$ & -146 & -6.06 \\
\cline { 2 - 5 } & 발화 말 & $706( \pm 463)$ & & \\
\hline \multirow{2}{*}{ 과제***** } & 낭독 발화 & $431( \pm 319)$ & -72.85 & -2.49 \\
\cline { 2 - 5 } & 자유 발화 & $525( \pm 415)$ & & \\
\hline \multirow{2}{*}{ 성별 } & 남성 & $546( \pm 422)$ & 37.36 & 1.27 \\
\cline { 2 - 5 } & 여성 & $460( \pm 371)$ & & \\
\hline \multirow{2}{*}{ 세대 } & 청년 & $475( \pm 359)$ & -20.923 & -0.71 \\
\cline { 2 - 5 } & 장년 & $553( \pm 444)$ & & \\
\hline \hline
\end{tabular}

${ }^{* * * *} p<0.001$.

통계 검정 결과, 호흡을 동반하지 않은 휴지의 길이는 호흡 동반 휴지보다 변수에 따른 차이가 두드러지지 않은 것으로 나 타났다. 표 6에서 확인할 수 있듯이, 들숨 비동반 휴지 길이에 영 향을 주는 요인은 실현 위치와 과제뿐이었다. 실현 위치의 경우 특히 큰 차이가 관찰되었다 $(p<0.001)$. 발화 내 휴지와 발화 말 휴 지가 각각 $481 \mathrm{~ms}, 706 \mathrm{~ms}$ 의 평균값을 보였다. 과제에서도 낭독 발화와 자유 발화가 각각 $431 \mathrm{~ms}, 525 \mathrm{~ms}$ 의 평균값을 보여서 큰 차이를 관찰할 수 있었다 $(p<0.001)$. 성별과 세대의 경우 남성이 여성보다, 장년층이 청년층보다 다소 긴 들숨 비동반 휴지를 보 였으나 그 차이가 통계적으로 유의미하지는 않았다.

한편, 단일 변수에 따른 주효과 이외에 들숨 비동반 휴지에 영향을 주는 상호작용 효과는 관찰되지 않았다.

본 연구의 결과를 정리하면 다음과 같다. 전체적인 휴지 양상 을 살펴본 결과, 휴지 길이에 영향을 주는 것은 실현 위치, 과제, 성별임을 확인하였다. 들숨 동반 휴지의 경우에도 마찬가지로 실현 위치, 과제, 성별의 주효과가 관찰되었다. 전체적으로 발화 내보다는 발화 말 위치에서, 낭독 발화보다는 자유 발화에서, 남성이 여성보다 더 긴 휴지를 보였다. 들숨 비동반 휴지 역시 다른 휴지 유형과 실현 양상이 유사했으나, 실현 위치와 과제에 서만 유의한 차이가 있었다. 한편 전체적인 휴지 길이는 실현 위치와 성별 간 상호 작용 효과가 있음이 확인되었다. 남성은 여 성보다 전체적으로 긴 길이의 휴지를 두고 발화하는데, 이 차이 는 특히 발화 말에서 두드러졌다.

\section{4. 논의}

4.1. 실현 위치에 따른 휴지 길이 차이

이 연구에서 우리는 휴지의 실현 위치를 발화 내와 발화 말로 구분하였다. 휴지의 길이를 측정하여 관찰한 결과, 모든 휴지 유 형에서 실현 위치에 따른 차이가 유의했다. 3.2.2.절과 3.2.3. 절에 에서 살펴보았듯이, 들숨 동반 여부에 무관하게 발화 말 휴지가 발화 내 휴지보다 긴 것을 일관되게 확인할 수 있었다. 들숨 동 반 휴지의 경우 발화 말 휴지 길이는 $685 \mathrm{~ms}$, 발화 내 휴지 길이 는 $573 \mathrm{~ms}$ 이었고 들숨 비동반 휴지의 경우 발화 말에서 $706 \mathrm{ms,}$ 발화 내에서 $481 \mathrm{~ms}$ 의 길이를 보였다. 그리고 발화 말 휴지와 발 화 내 휴지의 이러한 길이 차이는 통계적으로도 유의한 차이임 을 확인하였다.

이러한 결과는 휴지의 길이가 발화에서 일정한 기능을 수행 하고 있음을 확인해 준다. 이미 많은 연구들에서 발화 내 휴지 와 발화 말 휴지의 기능이 다르다는 것이 보고된 바 있다(Ahn, 2007; Yorkston et al., 1988). 앞선 연구들에 따르면 발화 내 휴지 는 음운·형태·통사론적 단위에 의해 실현될 가능성이 높은 휴지 인 반면, 발화 말 휴지는 후행 발화를 계획하기 위한 인지적 이 유로 인해 실현될 가능성이 높다. 일반적으로 인지적 부담이 더 큰 위치에서 더 긴 휴지가 실현되는 것이 자연스러우므로 발화 내 위치보다 발화 말 위치에서 더 긴 휴지가 관찰되는 것은 예 상되는 결과라고 할 수 있다.

휴지 두기(pausing)는 화자에게 다음에 올 발화를 계획할 수 있는 시간을 제공한다(Butcher, 1981; Goleman-Eisler, 1968; Levelt, 1989). 한 발화가 종결되면 화자는 다음 발화를 위한 계획을 수 행해야 한다. 화자는 계획을 위한 시간을 벌기 위해 발화에서 긴 휴지를 실현시킨다. 한편 한 번 발화 계획을 완료하고 나면, 화 자는 계획된 발화를 일정한 문법적, 운율적 단위로 끊어서 산출 하게 되는데 그 과정에서 휴지가 실현될 수 있다. 또한 이미 계 획된 발화를 산출하는 과정에서, 강조와 같은 화자의 발화 전략 이나 더듬거림과 같은 말실수에 의해서도 휴지가 나타날 수 있 다. 이런 이유로 실현되는 발화 내 휴지는 발화 말 위치에 비해 상대적으로 더 적은 양의 인지적 부담을 갖기 때문에 더 짧은 휴지가 관찰되는 것으로 해석할 수 있다.

이처럼 휴지는 발화에 나타나는 위치에 따라 기능과 실현 양 상이 달라진다. 휴지의 여러 기능 중 하나는 발화를 일정한 운율 적 단위에 따라 구분하거나 시간적 등시성을 표현해주는 역할 을 하는 것이다(Barbosa \& Bailly, 1993; Zellner, 1994). 즉, 휴지는 운율 경계를 신호하는 데 있어 일종의 길이의 정규성(durational regulation)을 갖는다(Zellner, 1994).

본 연구의 결과는 휴지 길이가 발화의 종료 혹은 비종료를 표 시하는 기능을 체계적으로 수행하고 있음을 보여준다. 들숨이 동반되는가, 동반되지 않는가와는 무관하게 일반적으로 발화 내는 약 500 600 ms 이하의 휴지가, 발화 말에는 약 $600 \mathrm{~ms}$ 이상 의 휴지가 관찰된다. 중앙값을 기준으로 살폈을 때에도 발화 내 들숨 동반 휴지 길이는 $487 \mathrm{~ms}$, 발화 말 들숨 동반 휴지 길이는 $580 \mathrm{~ms}$ 였으며, 들숨 비동반 휴지의 경우 발화 내 위치에서는 
$344 \mathrm{~ms}$, 발화 말 위치에서는 $617 \mathrm{~ms}$ 의 길이를 보였다. 중앙값을 기준으로 보았을 때에도 발화 내 휴지 길이는 대략 $500 \mathrm{~ms}$ 이하 에, 발화 말 휴지 길이는 약 $600 \mathrm{~ms}$ 이상에 분포하는 것을 알 수 있었다.

한편 발화 내 휴지와 발화 말 휴지의 평균 길이 차이가 160 $\mathrm{ms}$ 이상이라는 점도 주목할 만하다. 휴지의 전체적인 실현 양상 을 살펴보았을 때, 발화 말 휴지와 발화 내 휴지의 평균 길이 차 이는 $172 \mathrm{~ms}$ 이었고, 중앙값 기준으로는 발화 말 휴지 길이가 $590 \mathrm{~ms}$, 발화 내 휴지 길이가 $424 \mathrm{~ms}$ 로 그 차이는 $166 \mathrm{~ms}$ 였다. Lee et al.(2017)의 연구를 바탕으로 우리는 한 음절당 조음 시 간을 계산할 수 있다. 이 연구에 따르면 한국어의 평균 조음 속도는 초당 5.99 음절이므로 음절당 지속 시간을 계산하면 $166.94(1,000 / 5.99) \mathrm{ms}$ 가 된다. 따라서 본 결과에서 관찰된 약 160 $\mathrm{ms}$ 이상의 차이는 운율 단위를 기준으로 한 음절 정도의 차이를 반영한다고 할 수 있다. 이처럼 휴지의 길이는 일정한 운율적 정 규성을 가지고 발화 단위의 종결이나 비종결를 신호하는 데 주 요한 역할을 수행하는 것으로 보인다.

운율적인 경계를 신호하는 것이 휴지의 주요 기능이라는 점 에서, 발화 말 휴지의 기본적인 기능은 발화 단위의 종결을 신호 하는 것으로 이해할 수 있다. 일정 정도 시간 이상의 휴지가 출 현하면 청자는 발화가 종결되었음을 지각한다. 그러나 지나치 게 긴 시간 동안 휴지가 실현되면 이는 부적절한 발화 수행으로 간주된다. 화자는 한 발화가 종결되었음을 신호하면서도, 전체 적인 대화가 아직 종결되지 않았음을 나타내기 위하여 적당한 정도의 발화 말 휴지 길이를 실현하는데, 그 길이는 $600 \mathrm{~ms}$ 이상 이다.

4.2. 과제, 세대, 성별에 따른 휴지 실현

\subsection{1. 과제별 차이}

과제에 따라 차이를 보이는 변수들은 휴지 빈도, 전체 휴지 길이, 들숨 동반 휴지 길이, 들숨 비동반 휴지 길이였다. 자유 발 화는 낭독 발화에 비해 휴지 길이와 들숨 동반 휴지 길이 모두 길었고 휴지의 빈도도 높았다. 다시 말해 자유 발화에서는 빈번 하고 긴 휴지가 관찰되는 반면 낭독 발화에서는 짧은 휴지가 주 로 관찰된다. 휴지 길이의 이러한 과제별 차이는 난이도가 더 어려운 자유 발화 과제에서 휴지의 길이가 더 길어진다고 보고 한 Goldman-Eisler(1958; 1968)의 연구와 일치하는 결과이다.

이러한 과제별 차이는 인지적 부담량에 따른 차이인 것으로 보인다. Cappella(1985)는 화자가 더 큰 인지적 부담 아래 놓일 때 더 긴 휴지 사용을 야기한다고 하였다. 자유 발화의 경우, 화 자의 즉각적이고 적극적인 발화 계획이 요구되기 때문에 낭독 발화보다 더 인지적인 부담이 발생한다. 따라서 더 긴 휴지가 나 타나는 것은 자연스럽다.

휴지는 언어적 내용 정보를 담고 있지 않는 요소이다. 화자는 발화를 이어가기 위해 계속해서 정보를 생산해 내야 하는데, 이 과정에서 휴지를 두게 된다. Zellner(1994)에 따르면, 휴지는 최 종 산출물(final output)이 계획되고 조직되는 동안, 추가적인 시 간(additional time)을 제공한다. 즉 정보가 없는 휴지를 출현시킴
으로써 시간을 벌고, 그 시간 동안 후행 발화의 정보를 계획하는 것이다. 따라서 더 적극적인 정보 생산 활동이 필요한 자유 발 화에서 더 길고 빈번한 휴지가 출현하는 것은 당연한 결과라고 할 수 있다.

뿐만 아니라 $\operatorname{Shin}(2018)$ 에서 언급했듯 휴지는 청자에게도 화 자로부터 들어온 발화 정보를 처리할 수 있는 시간을 제공한다. 휴지는 정보를 가지고 있지 않기 때문에 화·청자 모두에게 언어 적인 정보를 처리할 수 있는 시간을 제공한다. 자유 발화는 낭독 발화보다 화·청자를 위한 시간이 더 많이 필요한 발화 과제이므 로, 더 긴 휴지가 관찰된다.

휴지의 빈도 역시 과제 간 차이를 보였다. 낭독 발화에서는 분당 휴지 출현 빈도가 21.9회, 자유 발화에서는 26회였다. 같은 양의 발화를 하더라도 자유 발화에서 더 많은 휴지가 관찰되는 것이다. 이는 낭독 발화보다 자유 발화에서 더 다양한 기능의 휴지가 실현될 수 있기 때문이다.

휴지는 운율적 정규성(prosodic regulation)을 신호하거나 문법 적인 단위를 구분해주는 역할을 하기도 하지만, 발화 전략상의 이유나 비유창한 발화 수행에 의해 동반되기도 한다. 그런데 낭 독 발화는 여러 기능의 휴지가 실현될 일이 거의 없다. 낭독 발 화의 경우 대본이 주어져 있으므로 화자는 대체로 이를 일정한 운율적, 문법적 단위에 따라 끊어 읽게 된다. 이때 화자는 특별 한 발화 전략을 위해 휴지를 삽입할 일이 거의 없고, 자유 발화 에서처럼 발화 실수를 동반할 가능성도 적다. 반면 자유 발화에 서 관찰되는 휴지는 운율적이고 문법적인 단위를 구분해주는 역할부터 발화 계획을 위한 것, 또 발화 수행 오류에서 나타나 는 것까지 훨씬 더 다양한 기능을 갖는다. 따라서 같은 양을 발 화하더라도 자유 발화에서 더 빈번한 휴지가 출현하는 것은 자 연스럽다.

\subsection{2. 성별 차이}

성별에 따라 차이를 보이는 변수는 휴지 빈도, 전체 휴지 길 이, 들숨 동반 휴지 길이였다. 남성은 여성보다 발화에서 더 자 주 휴지를 실현시켰고, 휴지의 길이도 길었다. 특히 들숨을 동반 하지 않을 때보다 들숨을 동반했을 때 남성의 휴지 길이가 더 길었다.

남성의 발화가 여성의 발화보다 더 길고 빈번한 휴지 출현 을 보인다는 결과는 영어를 대상으로 연구한 Kowal et al.(1975), Kowal \& O'Connell(1980), Kendell(2009)의 결과와 같았다. 그런 데, 본 연구에서 남녀 간 휴지 길이의 차이는 들숨 동반 여부에 따라 다소 다르게 나타났다. 들숨 동반 휴지 길이는 성별에 따 른 차이가 유의했던 반면, 들숨을 동반하지 않은 휴지의 경우 남녀 간 유의미한 차이가 없었다. 다시 말해, 휴지 길이의 남녀 차이를 야기하는 것은 들숨 여부이다.

3.2.2. 절에서 확인할 수 있듯이, 들숨 동반 휴지 길이는 남성 이 평균 $728 \mathrm{~ms}$, 여성이 평균 $601 \mathrm{~ms}$ 로 평균 $127 \mathrm{~ms}$ 차이를 보였 다. 반면 들숨 비동반 휴지의 경우 남성은 $546 \mathrm{~ms}$, 여성은 $460 \mathrm{~ms}$ 의 길이를 보여 남성이 평균 $86 \mathrm{~ms}$ 정도 길게 쉬었으나, 그 차이 는 통계적으로 유의하지 않았다. 
들숨 동반 휴지에서만 성별 차이를 보이는 이유는 들숨 동반 휴지가 신체적인 특성과 더 유관한 변수이기 때문이다. 일반적 으로 폐활량이 더 큰 집단은 일회호흡량(Tindal volume)2이 더 큰데, 여성은 남성에 비해 폐의 용량이 작기 때문에 일회 호 흡량이 적어 더 얕고 짧은 쉼을 쉬는 경향이 있다(LoMauro \& Aliverti, 2018). 남성은 여성에 비해 폐활량이 더 크기 때문에 (Lee, 2001; Schoenberg \& Bouhuys, 1978), 여성보다 더 많은 양의 기류를 조달해야 한다. 따라서 들숨을 위한 시간이 더 많이 필요 한 남성의 휴지 길이가 더 길게 나타난다.

한편 들숨 비동반 휴지는 성별 차이를 드러내지 않는다. 들숨 을 동반하지 않는 휴지는 기류 조달의 목적이 아닌 언어적, 준 언어적 목적을 위해 나타난다. 따라서 이는 남성과 여성의 신체 적인 차이를 반영할 가능성이 거의 없다. 다시 말해 기류 조달 의 목적이 아니라면, 휴지는 성별에 상관없이 일정한 정도의 정 규성을 갖는다고 할 수 있다.

\subsection{3. 실현 위치와 성별 간 상호 작용 효과}

휴지 길이를 살핀 3.2.1.절에서 휴지의 길이가 실현 위치와 성 별에 따른 상호 작용 효과가 있음을 밝혔다. 앞선 그림 2에서 확 인할 수 있었듯, 성별 차이를 두드러지게 보여주는 휴지의 위치 는 발화 말이다. 전체적으로 남성이 여성보다 더 긴 휴지 길이 를 보이지만 그 차이는 발화 말에서 더 크다. 평균적으로 남성 의 발화 말 휴지는 $787 \mathrm{~ms}$, 여성은 $626 \mathrm{~ms}$ 으로 약 $160 \mathrm{~ms}$ 정도의 차이를 보인다. 반면 발화 내 휴지 길이는 남녀 각각 $554 \mathrm{~ms}, 493$ $\mathrm{ms}$ 로 $60 \mathrm{~ms}$ 의 차이에 불과하다.

일종의 시간적 정규성을 알리는 기능을 수행하는 휴지가 발 화 말 위치에서 남녀 간 차이를 보인다는 점은 흥미롭다. 이는 호흡이 동반된 휴지가 주로 발화 말에서 실현되는 것과 연결지 어 생각해 볼 수 있으므로 남녀의 생리적 차이라고 해석할 수 있 다. 하지만 그 차이가 어디에서 기인한 것이든 남성과 여성의 발 화 말에서 약 $160 \mathrm{~ms}$ 정도의 차이를 가지고 실현된다는 점에 주 목할 필요가 있다. $160 \mathrm{~ms}$ 정도의 차이는 1 음절 정도의 차이를 의미하기 때문이다.

이 결과는 발화 말에서 남성이 여성에 비해 약 1음절 정도의 휴지를 더 두고 발화를 이어가는 것으로 해석할 수 있다. 발화 내 휴지는 큰 차이를 보이지 않지만 발화 말에서 1 음절 정도의 차이를 가지고 실현되는 휴지의 남녀 차이는 남성과 여성에게 서로의 발화에 대한 다른 인상을 갖게 할 것이다. 즉, 남성은 여 성의 발화가 늘 한 발짝 빨리 이어진다는 인상을, 여성은 남성의 발화가 늘 한 발짝 늦게 이어지는 인상을 갖게 할 것이다.

발화 말이란 말차례 교체가 가장 빈번하게 이루어지는 지점 이다. 따라서 발화 말에서 관찰되는 남녀 간 약 1 음절 정도의 휴 지 차이는 말차례 교체 시점에 대한 서로 다른 해석을 초래할 수 있다. 남성은 자신의 기대보다 한 음절 먼저 이어지는 여성 의 발화를 들으며 여성들이 끼어들 틈을 주지 않는다고 생각할
수 있다. 남성이 여성의 발화에 갖게 된 이러한 인상은, 남성들 이 갖는 일반적인 통념, 즉 여성들은 이야기할 때 끼어들 틈을 안 준다거나, 여성들과 말할 때 끼어들기가 어렵다는 것과 연결 되는 것이 아닌가 생각된다. 물론, 이러한 운율적 경계에 대한 남녀 간 차이는 산출 실험을 바탕으로 추론한 것이므로, 실제로 성별에 따라 운율적 경계 인식에 차이를 보이는지 확인하기 위 해서는 관련된 지각 실험이 후행되어야 할 것이다.

\subsection{4. 세대 차이}

세대에 따라 차이를 보이는 변수는 휴지 빈도뿐이었다. 장년 층 화자는 청년층 화자에 비해 휴지를 자주 실현했다. 휴지의 길 이의 경우, 대체로 장년층이 청년층보다 다소 긴 휴지 길이를 보 였으나 통계적으로 유의한 차이는 아니었다. 휴지 길이는 과제 나 성별에 따른 차이는 드러내지만 세대 차이를 보이는 변수는 아님을 알 수 있다.

또, 폐활량과 같은 신체적 특성을 반영하기 때문에 세대에 따 라 차이를 보일 것으로 예측되었던 들숨 동반 휴지 길이 역시 세대 간 차이가 발견되지 않았다. 나이가 듦에 따라 폐활량이 줄 어드는 것은 일반적인 경향이지만(Schoenberg et al., 1978), 이 는 흡연과 같은 개인의 습관에 영향을 받는다(Lee et al., 2000). 따라서 노화 과정에서 개인차가 크게 작용할 수 있다. 지속적으 로 흡연을 한 화자와 흡연을 하지 않은 화자 모두 나이가 듦에 따라 폐활량이 줄어들 것이나, 그 차이는 흡연을 지속적으로 한 화자가 더 클 것이다. 즉, 한 개인 안에서 나이에 따른 폐활량의 차이는 유의할 수 있지만, 집단 간 비교를 할 경우 개인 차이가 집단 간 차이를 상쇄시킬 가능성이 있다. 이로 인해 세대에 따른 차이가 관찰되지 않은 것으로 보인다. 그러나 성별 차이는 한 개인의 노화에 따른 차이를 반영하는 것이 아니므로 개인 차이 가 집단 간의 차이를 상쇄시키지 못한다. 이 때문에 성별은 들숨 동반 휴지 길이 실현에 영향을 주는 변수였지만 세대는 그렇지 않았던 것으로 보인다.

그런 데 세대 간 휴지 길이의 차이가 없다는 것이 청·장년층의 전체적인 발화 패턴이 유사함을 의미하는 것은 아니다. Lee et al.(2017)에서도 언급했듯이, 휴지부의 비율은 장년층이 청년층 에 비해 유의미하게 높다. 본 연구에서도 장년층의 휴지부 비율 은 $24.6 \%$ 로, 청년층의 $21.8 \%$ 보다 더 높았다. 이는 장년층의 휴 지 빈도가 훨씬 더 빈번했기 때문이다. 휴지 각각의 길이는 청. 장년층이 차이를 보이지 않지만, 장년층 화자는 발화에서 휴지 를 더 많이 실현시킨다. 따라서 전체적으로는 장년층의 발화에 서 휴지가 차지하는 양이 청년층의 발화보다 많아지는 것이다.

이러한 사실은 전체적인 장년층 화자의 발화 인상을 결정한 다. 즉, 실제 각각의 휴지 길이는 청년층과 차이가 없더라도, 장 년층의 발화는 휴지가 많이 나타날 것 같은 인상을 받는다. 만약 청자가 어떤 발화를 듣고, 실현된 휴지 양상에 따라 세대 차이 를 느낀다면 이는 휴지 길이에 의한 인상이 아니라 휴지 빈도에 
따른 인상에서 기인했을 가능성이 높다. 단, 이러한 청자의 인상 적 판단이 사실인지 확인하기 위해서는 세대에 따른 발화 수행 에 대한 지각적 연구가 뒷받침되어야 할 것으로 보인다.

\section{5. 결론}

본 연구는 한국어 발화를 대상으로 과제, 세대, 성별이라는 변수가 휴지 실현에 어떠한 영향을 미치는지 살펴보았다. 이를 위하여 대규모 구어 코퍼스인 '한국인 표준 음성 데이터베이스' 에서 세대, 성별에 따라 48명 화자를 선정하여 두 가지 발화 과 제를 분석하였다. 휴지는 발화에서 실현되는 위치와 들숨 동반 여부에 따라 들숨 동반 발화 말 휴지, 들숨 동반 발화 내 휴지, 들숨 비동반 발화 말 휴지, 들숨 비동반 발화 말 휴지로 구분하 여 살펴보았고 각각의 빈도와 길이를 측정하였다.

실현 위치에 따른 휴지 길이를 살펴본 결과, 본고는 휴지의 길 이가 발화의 종료 혹은 비종료를 표시하는 기능을 체계적으로 수행하고 있음을 밝혔다. 일반적으로 발화 내에는 약 500 600 $\mathrm{ms}$ 이하의 휴지가, 발화 말에는 약 $600 \mathrm{~ms}$ 이상의 휴지가 관찰되 었다. 휴지의 전체적인 실현 양상을 기준으로 발화 말 휴지와 발 화 내 휴지의 평균 길이 차이는 $172 \mathrm{~ms}$ 로 나타났는데, 이는 약 한 음절을 산출하는 것과 유사한 길이였다. 음절이 운율 구조에 서 가장 작은 단위임을 고려했을 때, 한 음절만큼의 차이는 운율 적으로 일정한 차이를 나타낸다. 즉, 운율적 정규성을 보이는 것 이다. 정리하면 휴지는 발화에서 일정한 운율적 정규성에 따라 발화의 종료 내지 비종료를 신호하는데, 약 $600 \mathrm{~ms}$ 이상의 휴지 가 나타날 때에는 발화의 종료를, 약 500 600 ms 이하의 휴지가 나타날 때에는 발화의 비종결을 신호한다.

한편 과제에 따라 차이를 보이는 것은 휴지 빈도, 휴지 길이 였다. 자유 발화는 낭독 발화보다 휴지가 많이 실현되며 그 길 이 또한 길다. 이는 화자의 즉각적이고 적극적인 발화 계획이 요구되는 낭독발화가 필연적으로 더 길고 빈번한 휴지를 야기 하기 때문이다. 계획이 요구되는 곳에서 긴 휴지를 갖는 것은 매 우 자연스러운 결과이다. 또 자유 발화는 낭독 발화에서보다 더 다양한 기능의 휴지가 실현될 가능성이 크므로 같은 양을 발화 하더라도 자유 발화에서 더 빈번한 휴지가 출현하는 것 역시 자 연스러운 결과이다.

성별에 영향을 받는 것은 휴지 빈도, 전체 휴지 길이, 들숨 동 반 휴지 길이였다. 전반적으로 남성은 여성보다 길고 빈번한 휴 지를 보였다. 그런데 호흡과 관련이 없는 들숨 비동반 휴지 길 이는 성별 차이가 없었다. 이는 폐활량과 관련이 있는 것으로 보인다. 남성은 들숨을 더 깊게 쉬기 때문에 들숨 동반 휴지가 길어진다. 그러나 들숨을 동반하지 않는 휴지는 호흡을 위한 휴 지가 아니므로 성별에 따른 신체적 차이를 드러내지 않는다.

이 밖에도 변수 간 상호 작용 효과가 관찰되었는데, 휴지 길 이에 대하여 실현 위치와 성별 간 상호 작용 효과가 있었다. 휴 지 길이의 성별 차이에 따르면 남성이 여성보다 휴지 길이가 긴 데, 이는 특히 발화 말 휴지에서 두드러졌다. 발화 말 휴지 길이 의 남녀 차이는 평균 $161 \mathrm{~ms}$ 로, 발화 내 휴지 길이의 성별 차이
의 평균이 $61 \mathrm{~ms}$ 인 것에 비해 큰 값으로 나타났다. 발화 말 휴지 는 한 발화의 종결과 후행 발화가 시작까지의 시간적 거리이다. 남성의 발화 말 휴지 길이가 $161 \mathrm{~ms}$ 더 길다는 것은, 남성이 한 발화를 끝내고 다음 발화를 이어갈 때 여성보다 발화 말에서 1 음절 가량의 시간을 더 필요로 한다는 것을 의미한다. 발화 말 은 말차례 교대가 가장 빈번하게 이루어지는 지점이다. 따라서 발화 말에서 남녀 간 약 1음절 정도의 휴지 길이 차이를 보인다 는 점은 적절한 말차례 교대 시점에 대한 남녀 간 인식 차이를 초래하는 것으로 보인다.

세대에 영향을 받는 변수는 휴지 빈도뿐이었고 휴지 길이는 세대 차이를 보이지 않았다. 이는 휴지 길이 자체가 세대 차이 를 드러내주는 변수는 아님을 의미한다. 그러나 세대 간 휴지 길 이의 차이가 없다는 것이 세대 간 발화 패턴이 유사함을 의미하 지는 않는다. 본고의 연구 결과 각각의 휴지 길이는 청·장년층 이 유사했으나 장년층이 발화를 이어갈 때 더 자주 휴지를 둔다 는 것을 발견하였다. 이로 인해 발화 전체적으로 장년층 발화의 휴지가 차지하는 비율이 더 높아진다. 이러한 사실은 전체적인 장년층 화자의 발화 인상을 결정한다. 즉, 휴지의 길이 자체에는 차이가 없더라도 장년층의 발화는 휴지가 많이 개입된다는 인 상적 판단을 만들어내는 것이다.

실제 구어 자료에 기반하여 한국어 발화에 나타나는 휴지를 과제, 세대, 성별에 따라 분석한 본 연구는 향후 한국어의 휴지 연구 전반에 대한 기초 연구가 될 것으로 보인다. 특히 운율적 정규성의 측면에서 휴지가 어떠한 역할을 수행하는지 구체적 으로 밝힌 연구가 거의 전무하다는 점에서 본 연구의 결과가 시 사하는 바가 더욱 의의가 있다고 할 수 있다. 이 연구는 유창성 의 측면에서도 병리학적 활용도가 있을 것으로 기대된다. 단, 휴 지 실현 양상은 언어 외적 변수가 아닌 언어 내부적 기제에 의 해서도 달라질 수 있다는 점에서, 각 문법 성분이나 담화 기능 에 따른 휴지 실현을 밝힐 수 있는 후속 연구가 필요하다. 이러 한 연구가 통합되었을 때 어떤 위치에서 어떤 종류의 휴지가 실 현되는지 정확하게 예측할 수 있을 것이며, 이런 연구들이 전산 학과 음성 공학 분야의 참고 자료로서 사용될 수 있을 것이다.

\section{References}

Ahn, B. S. (2007). A critical review of the studies on the functions of pause in Korean. The Study of Korean Language and Literature, $28,67-87$.

Barbosa, P., \& Bailly, G. (1993). Generation and evaluation of rhythmic patterns for text-to-speech synthesis. Proceedings of the an ESCA Workshop on Prosody (pp. 66-69). Lund, Sweden .

Butcher, A. (1981). Aspects of the speech pause: Phonetic correlates and communicative functions (Doctoral dissertation). University of Kiel, Kiel, Germany.

Cappella, J. N. (1985). The management of conversations. In M. L. Knapp, \& G. R. Miller. (Eds.), The handbook of interpersonal communication (pp. 393-438). Beverly Hills, CA: Sage. 
Clopper, C., \& Smiljanic, R. (2015). Regional variation in temporal organization in American English. Journal of Phonetics, 49, 1-15.

Ferreira, F. (1991). Effects of length and syntactic complexity on initiation times for prepared utterances. Journal of Memory and Language, 30(2), 210-233.

Goldman Eisler, F. (1968). Psycholinguistics: Experiments in spontaneous speech. London and New York: Academic Press.

Goldman-Eisler, F. (1958). The predictability of words in context and the length of pauses in speech. Language and Speech, 1(3), 226-231.

Goldman-Eisler, F. (1972). Pauses, clauses, sentences. Language and Speech, 15(2), 103-113.

Grosjean, F., Grosjean, L., \& Lane, H. (1979). The patterns of silence: Performance structures in sentence production. Cognitive Psychology, 11(1), 58-81.

Henderson, A., Goldman-Eisler, F., \& Skarbek, A. (1965). Temporal patterns of cognitive activity and breath control in speech. Language and Speech, 8(4), 236-242.

Henderson, A., Goldman-Eisler, F., \& Skarbek, A. (1966). Sequential temporal patterns in spontaneous speech. Language and Speech, 9(4), 207-216.

Kang, J. W. (2002). Respiratory physiology for inhalation sedation. Journal of the Korean Dental Society of Anesthesiology, 2(1),7-14.

Kendell, T. S. (2009). Speech rate, pause, and linguistic variation: An examination through the sociolinguistic archive and analysis project (Doctoral dissertation). Duke University, Durham, NC. USA.

Kowal, S., O'Connell, D. C., \& Sabin, E. J. (1975). Development of temporal patterning and vocal hesitations in spontaneous narratives. Journal of Psycholinguistic Research, 4(3), 195-207.

Kowal, S., \& O'Connell, D. C. (1980). Pausological research at Saint Louis University. In H. W. Dechert, \& M. Raupach(Eds.), Temporal variables in speech (pp. 61-68). Berlin: De Gruyter Mouton.

Lee, H. S., Kim, N. Y., In, D. H., Joo, H. D., Lee, J. B., Kam, S., \& Ye, M. H. (2000). Effect of smoking on pulmonary function in ex-smokers and current smokers. Korean Journal of Family Medicine, 21(2), 211-221.

Lee, N., Shin, J., Yoo, D., \& Kim, K. (2017). Speech rate in Korean across region, gender and generation. Phonetics and Speech Sciences, 9(1), 27-39.

Lee, S. G. (2001). Changes of body composition, physical fitness and cardiopulmonary functions of women by aging. The Korean Journal of Physical Education, 40(4), 707-717.

Levelt, W. J. M. (1989). Speaking: From intention to articulation. Cambridge: MIT Press.

LoMauro, A., \& Aliverti, A. (2018). Sex differences in respiratory function. Breathe, Sheffield, England, 14(2), 131-140.

Schoenberg, J. B., Beck, G. J., \& Bouhuys, A. (1978). Growth and decay of pulmonary function in healthy blacks and whites.
Respiration Physiology, 33(3), 367-393.

Shin, J. (2013). How to maximize efficiency of communication (1): A prosodic analysis. Journal of the Society of Korean Language and Literature, 69, 113-133.

Shin, J. (2018). Breath and memory in speech based on quantitative analysis of breath groups and pause units in Korean. Korean Linguistics, 79, 91-116.

Shin, J., \& Kim, K. W. (2017). Developing a Korean standard speech DB (II). Phonetics and Speech Sciences, 9(2), 9-22.

Smith, C. L. (2004). Topic transitions and durational prosody in reading aloud: Production and modeling. Speech Communication, 42, 247-270.

Wennerstrom, A., \& Siegel, A. F. (2003). Keeping the floor in multiparty conversations: Intonation, syntax, and pause. Discourse Processes, 36(2), 77-107.

Whiteside, S. P. 1995. Temporal-based speaker sex differences in read speech: A sociophonetic approach. Proceedings of the 13th International Congress of Phonetic Sciences(ICPhS 95) (Vol. 3, pp. 516-519).

Yorkston, K. M., Beukelman, D. R., \& Bell, K. R. (1988). Clinical management of dysarthric speakers. Boston, MA: Little, Brown \& Company.

Zellner, B. (1994). Pause and the temporal structure of speech. In E. Keller (Ed.), Fundamentals of speech synthesis and speech recognition (pp. 41-62). Chichester, UK: John Wiley.

\section{- 유도영 (Doyoung Yoo)}

고려대학교 국어국문학과 박사과정

서울시 성북구 안암로 145

Tel: 02-3290-2505

Email: doong723@korea.ac.kr

관심분야: 음성학, 음운론

- 신지영 (Jiyoung Shin) 교신저자 고려대학교 국어국문학과 교수 서울시 성북구 안암로 145

Tel: 02-3290-1972

Email: shinjy@korea.ac.kr 관심분야: 음성학, 음운론 


\section{부록 1. 낭독 대본}

남일이네 야옹이는 멍멍이를 미워합니다. 야옹이는 멍멍 이의 마음을 모릅니다. 그래서 멍멍이랑 놀아주지 않습니 다. 은행나무 위에는 야옹이만 올라옵니다. 무모한 멍멍이 는 나무 위로 날아오릅니다. 그렇지만 너무 높아서 오르기 가 어렵습니다. 야옹이는 매일매일 나무 위에 머무릅니다. 위에서 얄미운 울음만 웁니다. 나무 아래 누워있는 멍멍이 는 무료합니다. 야옹이는 야밤에만 아래로 내려옵니다. 우 울한 멍멍이는 애먼 나를 원망합니다. 


\title{
과제, 성별, 세대에 따른 휴지의 실현 양상 연구*
}

\author{
유 도 영·신 지 영 \\ 고려대학교 국어국문학과
}

\begin{abstract}
국문초록
이 연구의 목적은 한국어의 휴지 실현에 과제, 세대, 성별이라는 변수가 어떠한 영향을 미치는지 살펴보는 것이다. 이를 위해 구어 코퍼스에서 세대, 성별에 따른 총 48 명을 선정하여 두 가지 발화 과제 데이터를 분석하였다. 휴지는 발화에서 출현하는 위치와 들숨 동반 여부에 따라 들숨 동반 발화 말 휴지, 들숨 동반 발화 내 휴지, 들숨 비동반 발 화 말 휴지, 들숨 비동반 발화 말 휴지로 구분하여 살펴보았고 각각의 빈도와 길이, 그리고 휴지에 영향을 줄 수 있 는 다양한 요소들을 함께 살펴보았다. 그 결과 발화 말 휴지 길이가 발화 내 휴지 길이보다 약 $160 \mathrm{~ms}$ 이상 더 긴 것 을 확인하였다. 이는 휴지가 운율적 정규성을 가지며, 발화 말 휴지는 발화의 종결을 신호하는 역할을 체계적으로 수행한다는 것을 의미한다. 자유 발화는 낭독 발화보다 더 긴 휴지가 더 자주 나타나는 것을 확인하였다. 낭독 발화 에서는 화자의 즉각적이고 적극적인 발화 계획이 요구되기 때문이다. 성별의 경우 전반적으로 남성은 여성보다 길 고 빈번한 휴지를 보였다. 특히 들숨 동반 휴지는 남성이 여성보다 길었다. 세대의 경우 장년층이 청년층보다 더 자 주 휴지를 산출했다. 이 밖에도 변수 간 상호 작용 효과가 관찰되었다. 휴지 길이의 성별 차이에 따르면 남성이 여 성보다 휴지 길이가 긴데, 이는 특히 발화 말 휴지에서 두드러졌다.
\end{abstract}

핵심어: 휴지, 쉼, 사회언어학, 사회음성학, 발화 과제, 발화 스타일, 성별, 세대

\section{참고문헌}

가정의학회지, 21(2), 211-221.

강정완 (2002). 흡입진정에 필요한 호흡 생리. 대한치과마취과학 회지, 2(1), 7-14.

신지영 (2018). 언어 수행에서의 호흡과 기억. 한국어학, 79, 91-116. 신지영 (2013). 소통과 공감을 위한 전달력 높은 말하기의 언어학 적 조건(1): 운율적 측면을 중심으로. 어문논집, 69, 113-133. 신지영, 김경화 (2017). 한국인 표준 음성 DB 구축(II). 말소리와 음성과학, 9(2), 9-22.

안병섭 (2007). 휴지(pause)의 역할에 대한 반성적 검토. 우리어문 연구, 28, 67-87.

이나라, 신지영, 유도영, 김경화 (2017). 한국어 발화 속도의 지역, 성별, 세대에 따른 특징 연구. 말소리와 음성과학, 9(1), 27-39. 이사겸 (2001). 연령증가에 따른 여성의 신체구성과 체력 및 심폐 기능의 변화. 한국체육학회지, 40(4), 707-717.

이환석, 김난영, 임동현, 주형돈, 이정범, 감신, 예민해 (2000). 흡 연중단자 및 흡연자에 있어서 흡연이 폐기능에 미치는 영향.

* 이 논문은 2019년 대한민국 교육부와 한국연구재단의 지원을 받아 수행된 연구임(NRF-2017S1A5A2A01024742).

이 논문은 2019년 정부(교육부)의 재원으로 한국연구재단의 지원을 받아 수행된 연구임(한국연구재단-2018-글로벌박사양성사업). 